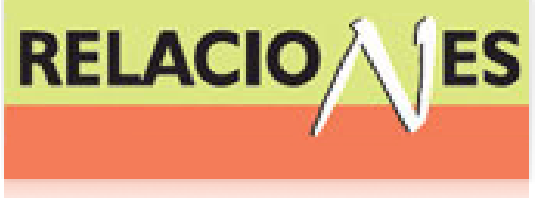

Relaciones. Estudios de historia y sociedad ISSN: 0185-3929

relacion@colmich.edu.mx

El Colegio de Michoacán, A.C

México

García Quintanilla, Alejandra

La langosta, los mayas y el colonialismo en Yucatán, México, 1883

Relaciones. Estudios de historia y sociedad, vol. XXXIII, núm. 129, 2012, pp. 215-249

El Colegio de Michoacán, A.C

Zamora, México

Disponible en: http://www.redalyc.org/articulo.oa?id=13723086007

Cómo citar el artículo

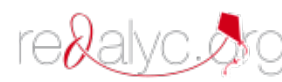

- Número completo

- Más información del artículo

Página de la revista en redalyc.org

Sistema de Información Científica

Red de Revistas Científicas de América Latina, el Caribe, España y Portugal Proyecto académico sin fines de lucro, desarrollado bajo la iniciativa de acceso abierto 
Sección temática

De langostas y otros flagelos

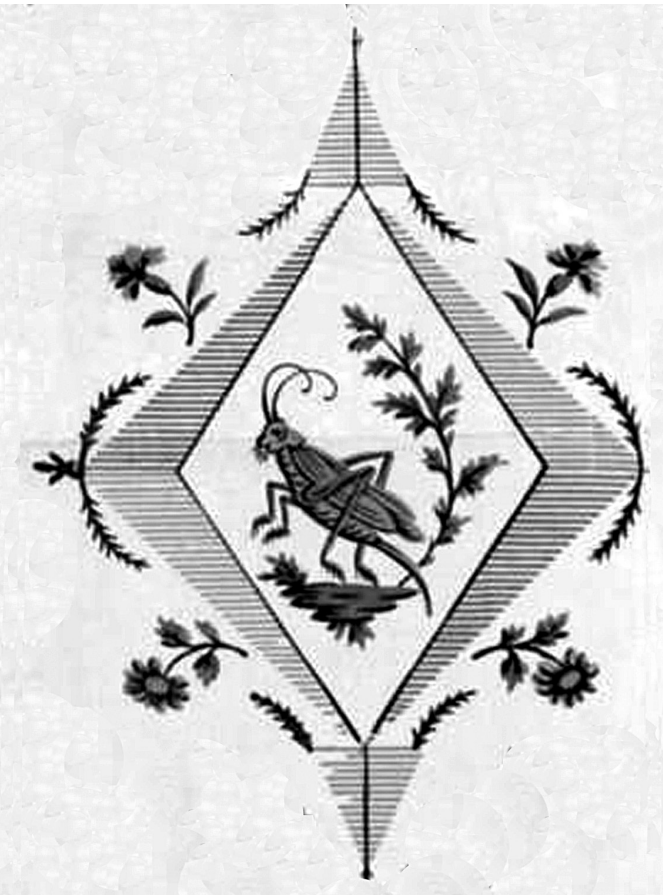




\title{
La langosta, los mayas y el colonialismo en Yucatán, México, 1883
}

\author{
Alejandra García Quintanilla* \\ UNIVERSIDAD AUTÓNOMA DE YUCATÁN
}

En 1883 se produjo una gran plaga de langosta que afectó a diversos estados de la República Mexicana. Tuvo su origen en Yucatán. Aquí se analizan las respuestas sociales de la sociedad civil integrada mayoritariamente por personas mayas, la de los hacendados henequeneros y también la del gobierno de Yucatán en lo que fue el inicio del llamado Auge Henequenero.

(Mayas, plaga de langosta, milpa, henequén, colonialismo)

\section{LA PLAGA Y EL CAMBIO CLIMÁTICO}

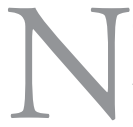

o se puede asegurar si fue en junio o a principios de julio, pero fue por la mańana y antes de que se intensificara la canícula de 1882. Fue entonces que empezaron a brotar de la tierra, donde las madres habían depositado los huevecillos. Es la humedad del rocío lo que acelera la maduración de sus organismos. La sequía, en cambio, la frena y hasta puede llegar a deshidratar los huevecillos. ${ }^{1}$ Desafortunadamente, en 1882 no se deshidrataron y

\footnotetext{
*gquintan@uady.mx alegarciaq@gmail.com

${ }^{1}$ El calendario del ciclo vital de la langosta viene de las observaciones realizadas por Pereyra, de julio de 1976 a diciembre de 1989 en Yucatán. Eudaldo Pereyra Cuevas, "Biología, ecología y control de la langosta Schistocerca piceifrons (Walker) (Orthoptera acrididae) en el Estado de Yucatán”, Tesis, Universidad Autónoma de Chapingo, 1991, 45-48; Ludivina Barrientos Lozano, et al., Manual técnico sobre la langosta voladora (Shistocerca piceifrons piceifrons Walker, 1870) y otros Acridiodeos de Centro América y Sureste de México, San Salvador, FAO-OIRSA, 1992, 15, 32-34; A.W. Harvey, "Schistocerca piceifrons (Walker) (Orthoptera: Acrididae), the Swarming Locust of Tropical America: a Review", Bulletin of Entomological Research 73, 1983, 177.
} 
de abajo salieron: muy pequeñas y muy torpes, con apenas unos muñones de alas que no les permitían volar. Los fémures de su tercer par de patas demasiado grandes, mucho más que los dos pares anteriores hacían de su andar un saltar. Por eso, en español se bautizó a las ninfas como "saltonas" y en maya takach, que Pío Pérez (siglo XIx) dijo que tiene dos significados: "de hito en hito", donde aparece la imagen de andar a saltos; y, "una especie de langosta". ${ }^{2}$

Bueno, pues tal vez en 1882, la sequía hizo que los hijos de la langosta maduraran más lentamente de lo habitual y no se volvieron adultos a principios de agosto, cuando regularmente sucede, sino hasta fines de mes y en septiembre, cuando empezaron a caer fuertes aguaceros. ${ }^{3} \mathrm{~A}$ las adultas se les distingue claramente de las ninfas porque poco antes de llegar a esa etapa, las alas se endurecen, empiezan a volar y luego maduran. Quizá fue bajo el influjo de las lluvias que, rápidamente, en unos 30 días, maduraron.

Pero los efectos de la sequía pueden ser más complejos. En Yucatán la sequía puede crear las condiciones para que la Schistocerca piceifrons piceifrons (Walker) se convierta en plaga. Así sucedió en 1882, cuando una canícula extraordinariamente intensa y larga propició la transformación completa de la piceifrons, la única especie de langosta que habita el sur de México y el norte de Centro América, es decir, el área maya. Es un insecto polimórfico que cambia, se transforma. Normalmente es un insecto solitario, un simple "chapulín" o saltamontes y se confunde a veces con las cigarras y los grillos por su color verde. Pero no siempre es verde, y aunque nunca es un insecto social como las abejas o las hormigas, sí tiene otra fase que es temible: cuando se vuelve gregaria. En la fase solitaria provoca algunos dańos, pero cuando se gregariza, su voracidad aumenta, vuela en mangas y adquiere la capacidad de migrar a grandes distancias. El instinto de volar o de migrar llega a predominar incluso so-

\footnotetext{
${ }^{2}$ Juan Pío Pérez, Diccionario de la lengua maya, Mérida, Imprenta Literaria, 1866$1877,316$.

3 "Buenas Noticias", La Revista de Mérida (en adelante LRM), 189 (24/08/1889), 2; véase Alejandra García Quintanilla, "Zaatal:Cuando los milperos perdieron el alma. Una historia de los mayas (Yucatán, 1880-1889)", cap. Iv, Tesis Doctoral, University of North Carolina at Chapel Hill, 1999, 44-56, La sequía tsul: racismo, clima, rebeldes.
} 
bre el de alimentarse en la langosta adulta, pero sexualmente inmadura, aunque totalmente gregarizada. Una manga en estas condiciones recorre entre 30 y $60 \mathrm{~km}$ al día, volando a alturas hasta de 1,000 m sobre el nivel del suelo. Lo importante es que cambia (de color, de tamaño, de hábitos, de fisiología). Para que estos cambios se desaten es necesario que haya poblaciones grandes y que empiecen a juntarse. Las inundaciones o las sequías (más frecuentes en Yucatán) pueden inducirlas a juntarse, a convivir en una alta densidad. Lo que sucede es que la sequía mata la vegetación y sólo quedan manchones de verde en el campo donde tienen que agruparse para comer. Al concentrarse empiezan a acostumbrarse a convivir y a transformarse en gregarias. Si las condiciones son adecuadas, se requieren tres generaciones sucesivas (que van heredando sus cambios) para llegar a la gregarización completa. Pero si las condiciones cambian, puede regresar a la fase solitaria o permanecer en transición durante más tiempo. Como presenta dos generaciones anuales, en dos años su transformación puede ser completa. La sequía de 1882 parece haber propiciado la consolidación de ese proceso porque después se dijo que desde 1880 ya la plaga invadía Oaxaca, Chiapas y Yucatán. ${ }^{4}$

Bien, pues en Yucatán el problema parece haber empezado a calar fuerte en 1883, cuando apareció en la prensa de Mérida devorando milpas y volando en grandes "mangas". Sin duda el gobernador respiró aliviado cuando hizo el recuento de 1882 e informó que: "Cuando se presentó la langosta, ya las sementeras estaban próximas a la cosecha y muy poco pudo destruir"; sólo 5,000 mecates (200 ha) de un total de 1,030,712 mecates (412,284.8 ha) de milpa. ${ }^{5}$ Pero aquel 1882 fue excesivamente angustioso para los campesinos, pues además de la sequía hubo epidemia de sarampión, luego de tos ferina y en el Registro Civil se anotaron más defunciones que naci-

\footnotetext{
${ }^{4}$ Ludivina Barrientos et al., op. cit., pp. 24, 28-29, 44-47; Eudaldo Pereyra Cuevas, op. cit., pp. 25-29, 50; Rodolfo Barreiro, "Secretaría de Fomento", La Unión Yucateca. Periódico del Estado Libre y Soberano de Yucatán (en adelante LUY), 112 (13/08/1883), 1-3.

5 "Mensaje leído por el Ejecutivo ante la Legislatura del Estado, al abrirse la Cámara el $1^{\circ}$ de enero de 1883", LUY, 22 (15/02/1883), 3-4.
} 
mientos. ${ }^{6}$ Ese mismo verano empezaron a pasar saltonas ya gregarizadas en bandas y luego volaron en gigantescas mangas que ensombrecieron los cielos, los suelos, y los corazones en Yucatán y también en los estados de Campeche, Tabasco y Veracruz. Los dańos no fueron muy graves entonces, porque cuando pasaron las saltonas, las milpas estaban ya destruidas por la sequía y apenas se estaban resembrando. Tal vez por eso la prensa yucateca no hizo mayor escándalo. Tal vez los periodistas pensaron que podrían librarse de la plaga. De todos modos, publicaron un reporte muy alarmante que les llegó desde Minatitlán, Veracruz el 10 septiembre del mismo 1882. Era del jefe político y era realmente perturbador:

El jueves siete fue tal la abundancia (de langosta) que desde las once de la mañana hasta las tres de la tarde, estuvo nublado el sol según lo compacto de la mancha que abrazaba un perímetro de cinco leguas (20.95 km); los caminos estuvieron interceptados, y el río se cubrió por espacio de cinco horas con una capa inmensa como de media vara $(0.419 \mathrm{~m})$ de espesor que la arrastraba la corriente, produciendo un sonido desagradable [...] durante la semana que hoy espira $[s i c]$ tuvo invadido todo el cantón, destruyendo a su paso árboles y todo lo que encontró; pero felizmente ya se había recogido toda la cosecha de maíz [...] que esta jefatura ordenó así se hiciera, por tener noticias de que el vecino estado de Tabasco estaba totalmente invadido. ${ }^{7}$

Para acabar de dramatizar esta situación bastarán algunos números elaborados por especialistas con base en observaciones más recientes de la Schistocerca piceifrons piceifrons (Walker). Una especie que en México (según las observaciones del siglo xix y xx²) sólo tie-

"Véase Alejandra García Quintanilla, "Mérida: El Sarampión de 1882", en Siglo XIX. Cuadernos de Historia, 1, 3, junio, 1992, 29-53; Alejandra García Quintanilla, op. cit., cap. vII: "El Santo Sarampión y el Santo Tosferina”, 1999, 114-137.

7 "La langosta en Minatitlán”, La Revista de Mérida (en adelante LRM), 221 (03/10/1883), 3 .

${ }^{8}$ En agosto de 1883 un agente de la Secretaría de Fomento escribió que en ese año la infestación era excepcional no sólo por sus dimensiones, sino porque siempre había estado limitada a los estados limítrofes con Centroamérica. En cambio en esta ocasión había llegado muy al norte y se había reproducido de manera excepcional. En Rodolfo Barreiro, "Secretaría de Fomento", LUY, 112 (13/08/1883), 1-3. 
ne un hábitat permanente donde se reproduce y gregariza y desde el cual migra cuando se convierte en plaga: el norte del territorio del actual estado de Yucatán. Los datos de los científicos me permiten confirmar los cálculos del jefe político de Minatitlán, pues están documentadas mangas de aproximadamente $20 \mathrm{~km}^{2}$ en 1954 . Sin embargo, sólo dispongo de datos sobre densidad e impacto para mangas menores de $10 \mathrm{~km}^{2}$. Se ha estimado que en esas mangas habrá 20 langostas por metro cuadrado. En esas condiciones de gregarización llega a su máxima voracidad y come su peso al día: unos $1.5 \mathrm{~g}$ de vegetación. En conjunto una manga de esas dimensiones puede devorar 300 toneladas de vegetación diarias. Pero se han observado mangas de 30 a 150 langostas por $\mathrm{m}^{2}$, lo que significa que las cantidades ingeridas podrían variar de 45 a $225 \mathrm{~g}$ por $\mathrm{m}^{2}$. Una manga con esa concentración, y de $10 \mathrm{~km}^{2}$ podría devorar entre 450 y 2,250 toneladas de vegetación al día. ${ }^{9}$ Por fortuna, no podré ser más precisa, pues producto de campańas internacionales, ya las mangas no han alcanzado los niveles necesarios para medir lo que en este artículo vamos a presentar. ${ }^{10}$

La catástrofe que veremos fue excepcional porque además de la canícula se produjeron otros cambios antropogénicos muy favorables a la plaga. A la piceifrons le gustan los lugares desmontados, quemados, pastizales, con maleza baja, los caminos o las veredas para copular y ovipositar. Cada hembra puede ovipositar unos 100 muy pequeños huevecillos por puesta aunque en estado gregario sólo unos 60 porque cambia su morfología y disminuye el número de ovariolos. ${ }^{11} \mathrm{Y}$ en 1882 , estaban abiertas grandes extensiones de selvas o "montes" que desde la década anterior se empezaron a tum-

\footnotetext{
${ }^{9}$ Ludivina Barrientos Lozano et al., op. cit., p. 20; A.W. Harvey, op. cit., p. 179; Eudaldo Pereyra Cuevas, op. cit., pp. 2, 6, 32; J. R. Parker y R.V. Connin, Langostas, sus hábitos y perjuicios, USDA-AID, 1967, 2 (citado por Pereyra).

${ }^{10}$ En 1940 se iniciaron las campañas "permanentes" y en colaboración internacional con Centroamérica. Pedro Trujillo G., El problema de la langosta, Tijuana, Sociedad de Geografía y Estadística de Baja California, Correspondiente Tijuana, 1975, III.

${ }_{11}$ Áreas que se caracterizan por tener altitudes de $100 \mathrm{msnm}$ o menos, dos estaciones (seca y lluviosa) bien definidas y temperaturas medias de $28^{\circ}$ a $32^{\circ} \mathrm{C}$. Ludivina Barrientos Lozano, et al., op. cit., pp. 20, 31, 34; Eudaldo Pereyra Cuevas, op. cit., pp. 50, 9-13, 46, 51-52; A. W. Harvey, op. cit., p. 176.
} 
bar para sembrar henequén (Agave fourcroydes) y esperar siete años para su maduración. Resultaron más que ideales para las piceifrons. ${ }^{12}$ Pero aún entre los "planteles" de henequén maduro (vive 17 años en producción) hay muchos claros agradables. Sí. En 1882, había muchos terrenos abiertos, con matitas pequeñas, a veces grandes o limpios, en espera de la siembra. ${ }^{13}$

Lamentablemente, los cambios provocados por los henequenizadores se combinaron con otros, de alcance planetario. El clima se dislocó en aquellos años. Sabemos que aquella plaga afectó a Veracruz, Tabasco, Campeche y Yucatán. Tal vez desde Guatemala llegó a Chiapas, Oaxaca e Hidalgo y a lugares donde el clima y la altitud no son los más favorables. ${ }^{14}$ Cuando forman gigantescas bandas y mangas son capaces de llegar hasta lugares que no reúnen las condiciones ideales de su hábitat natural, pues mientras que prefiere lugares situados a cien metros o menos sobre el nivel mar para su reproducción permanente y gregarización, también es capaz de llegar hasta los 2 mil msnm, cuando ha alcanzado su fase gregaria extrema. ${ }^{15}$ En Yucatán, las condiciones son ideales, pues el punto más alto llega apenas a $150 \mathrm{msnm}$, pero la mayor parte del territorio se encuentra por debajo de los $40 \mathrm{msnm}$. La ciudad de Mérida está a sólo $9 \mathrm{msnm} .{ }^{16}$ En 1883, fue capaz de llegar hasta los alrededores de Orizaba, Veracruz, a 1,227 msnn y tal vez cruzó la Sierra Madre.

Las condiciones ambientales del planeta se alteraron y hubo condiciones favorables para que saak, gregarizada y convertida en plaga, apareciera en varios lugares del continente americano. Está documentada una intensa sequía y una gigantesca infestación de langosta

\footnotetext{
${ }^{12}$ Sobre las siembras gigantes de los setenta, véase Alejandra García Quintanilla, "Producción de henequén, producción de hombres" en Mario Cerutti, ed., Cinco procesos regionales, México siglo XIX, México, Editorial Claves Latinoamericanas, 1985.

${ }^{13}$ Basado en observaciones de campo hechas en la década de 1960, Trujillo afirma que los planteles de henequén muy jóvenes y muy limpios de maleza, son especialmente favorables a la infestación. Véase Pedro Trujillo G., 1975, op. cit., p. 74.

14 "La langosta", $L U Y, 109$ (08/08/1883), 1; LUY, 127 (10/09/1883), 1; "Secretaría de Fomento", 112 (13/08/1883), 1.

${ }^{15}$ Ludivina Barrientos Lozano et al., op. cit., p. 31.

${ }^{16}$ Jorge Duch Gary, La conformación territorial del estado de Yucatán, México, Universidad Autónoma de Chapingo, 1988, 249-251.
} 
en 1883-1884, en Colombia. ${ }^{17}$ Allá también hay reportes sobre un intenso calentamiento de las aguas ecuatoriales en 1884: El Niño. Se sabe también que en esa década de 1880 se inició un cambio climático, un calentamiento global que -al menos para el hemisferio norte- duraría hasta la década de 1940. Y para agravar las cosas, y ya sea como causa o como consecuencia de tanto desbalance, el 27 de agosto de 1883, dos terceras partes de una isla, situada entre Sumatra y Java, desaparecieron cuando hizo erupción el Krakatoa. El estallido se escuchó a 3,000 km de distancia, el material volcánico alcanzó una altura de $80 \mathrm{~km}$ en la atmósfera y durante dos años circuló alrededor del planeta oscureciendo los cielos y causando alteraciones. Un desastre que se enlazaría con otros problemas volcánicos y con otro, muy intenso Nińo en $1889 .{ }^{18}$ Si fueron los volcanes o El Niño, es asunto de otras investigaciones. Por lo pronto, los problemas que vivieron los campesinos mayas de Yucatán en la década de 1880 quedan enmarcados no solamente como parte de transformaciones sociales locales que afectaron a las personas y al medio ambiente, sino como parte de una cadena de cambios planetarios.

El panorama era negro para los y las campesinas mayas de Yucatán. En 1883, los hombres y las mujeres no tendrían la posibilidad de recoger la cosecha antes de que pasaran las ninfas saltando, y luego las adultas volando, pero todas comiendo. Enfrentarían la plaga de 1883 en condiciones de debilidad porque sus reservas estaban mermadas por los estragos de la sequía de $1882 .{ }^{19}$ Algunos ya lo habían perdido todo entre la sequía, la piceifrons, y los henequenizadores. Para los mayas, profundos conocedores del clima y de su impacto sobre saak', el panorama habrá sido muy preocupante desde el verano del 1882. Es muy posible que lo anticiparan. En todo caso, las "profecías" de sus libros sagrados dan fe de su saber respecto de la relación entre sequía y langosta, y de que asociadas a estas dos cala-

\footnotetext{
${ }^{17}$ A. W. Harvey, 1983, op. cit., p. 179.

${ }^{18}$ Gerald G. Kuhn, "The Impact of Volcanic Eruptions on Worldwide Weather", 21st. Century. Science \& Technology, invierno 1997-1998, 51-54 y 48-58; Walter Orr Roberts y Henry Lansford, The Climate Mandate, San Francisco, W.H. Freeman and Company, 1979, 33, 68-70.

19 "Las cosechas de maíz", $L U Y, 48$ (09/04/1883), 1.
} 
midades, venían la mucha muerte y el mucho dolor. Estaba escrito en los libros sagrados, lo había asentado el Chilam (sabio) que recogió el saber y reconoció los signos:

Años vendrán de langostas, años fieros de lluvias fingidas, de lluvias de hilos delgados, escasa [...] Lluvia colgada del cielo, lluvia de lo muy alto, lluvia del zopilote celestial, lluvia angulosa, lluvia de venado, cuando bajen las hojas del silil: bullir de guerra y años de langosta [...] Grandes serán los montones de calaveras [...] y mucha será la carga de la miseria [...] No es mentira sino la palabra de Ku Likul Caanal. ¡Oh, vosotros, Hermanos Menores! Llanto de los pobladores, llanto de las Moscas en los cuatro caminos que se cruzan cuando golpee el katun destructor y griten las almas en las afueras de los poblados de los grandes Itzaes. ${ }^{20}$

\section{Yucatán i 883: La Carga de SaAk'}

El 30 de enero de 1883 hizo su primera aparición en la prensa de Mérida. Y aunque dijeron que ya la "nube" se veía "considerable", pues... Ni se dio la voz de alarma, ni se habló de peligro. Sólo ameritó el epíteto de "molestoso insecto". ${ }^{21} \mathrm{El} 14$ de marzo el gobernador dictó una orden en cuyo entrelineado parece contenerse la expectativa de que su desaparición era ya inminente. Hace un llamado a combatirla, pero no propone acciones y en lugar de ordenar, hace un delicadísimo llamado a los hacendados a colaborar con la gente de los pueblos en el combate a saak: "el Ejecutivo no duda un momento que los [...] propietarios [...] se prestarán gustosos a dar los auxilios". ${ }^{22}$ Sin embargo, lo más seguro es que estuviera lleno de dudas porque

${ }^{20}$ Los mayas han conocido muy bien a saak. Sobre sus saberes y símbolos véase Alejandra García Quintanilla, "'Saak' y el retorno del fin del mundo. La plaga de langosta en las profecías del katun 13 Ahau", en Ancient Mesoamérica 16, 2005, 327-344; Alfredo Barrera Vásquez, Silvia Rendón, El Libro de los Libros del Chilam, México, Fondo de Cultura Económica, 1948, 75, 170-171.

21 "Gacetilla", La Revista de Mérida (en adelante LRM), 317 (30/01/1883), 2.

${ }^{22}$ Eligio Ancona, Colección de leyes, decretos, órdenes y demás disposiciones de tendencia general: expedidas por el poder legislativo del estado de Yucatán, formada con autorización del gobierno, 31 de diciembre de 1850 hasta 30 de setiembre de 1858, volumen 6, Mérida, El Eco del Comercio, vol. 6, 1887, 339. 
Mapa. División política del estado de Yucatán (1900)

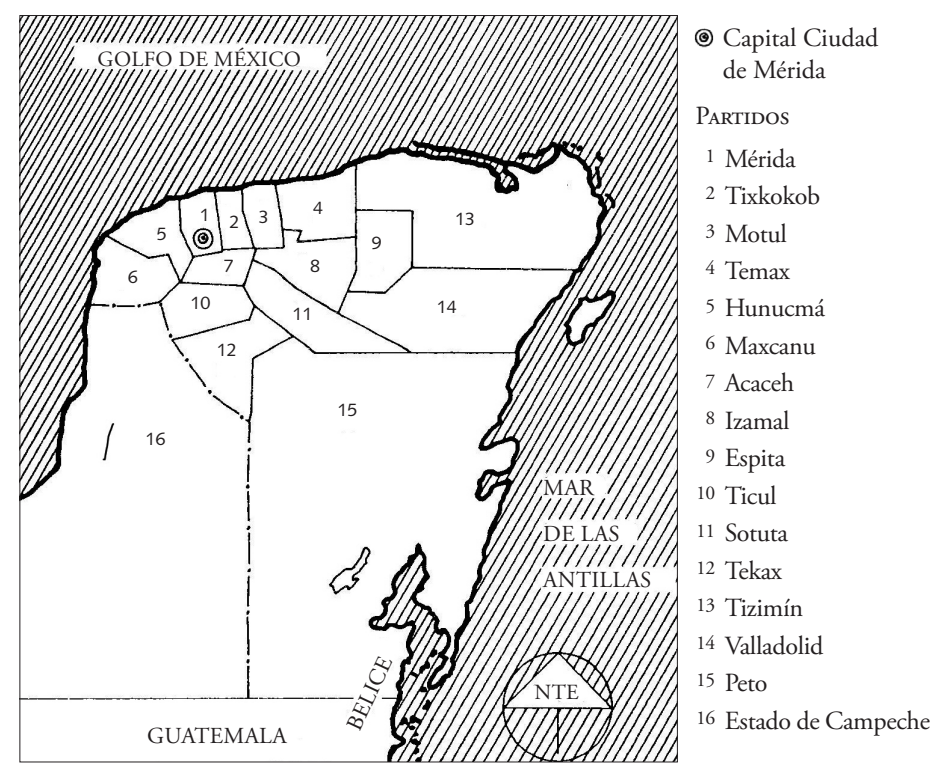

Fuente: Dibujo cortesía de Jorge Reyes Pérez, elaborado a partir de Estatutos de la Compañía de Ferrocarriles Sudorientales, AGEY, Mérida.

acababa de crear un impuesto a la fibra de henequén que lo había metido en una escandalosa disputa legal y política con los henequenizadores de la que ya iremos hablando. Para el 28 de mayo, reapareció en el Diario Oficial, pero estaba muerta. Era una "Recomendación" para evitar la contaminación del agua de lluvia, muy apreciada para beber, y que entonces, como hasta mediados del siglo $\mathrm{xx}$, se acostumbraba canalizar desde las azoteas hasta los aljibes para almacenarla: "que se limpien las azoteas de las casas, antes de que caigan las lluvias y estas arrastren a los aljibes las langostas muertas y las inmundicias que dejó el acridio pernicioso a su paso por esta capital". ${ }^{23}$

No parecía haber mayor apuro. Pero durante esos meses saak' maduraba, se volvía más voraz y unos días después, ¡empezó la ava-

23 “Recomendación”, $L U Y, 73$ (28/06/1883), 1. 
lancha en la prensa oficial! Aparentemente fue en respuesta a una orden del gobernador expedida el 25 de mayo en la que explica que su "gobierno ha sido informado de que en los campos se encuentra esparcida multitud de langosta muerta", y pide que se recoja, se queme y que en cada correo los jefes políticos informen de la situación en su partido. ${ }^{24}$ La gente del campo sólo necesitaba de un espacio para hacerse visible, porque el primer reporte es casi inmediato. Es del 27 de mayo y el presidente municipal de Opichén del partido de Maxcanú agregó una muy merecida felicitación del jefe político del partido a los habitantes del municipio por su entusiasta participación en el combate:

ayer a la tarde [26 de mayo] con toda la gente que me fue posible reunir, se comenzó la diligencia de mitigar cuanto más presta la fuerza del hombre, la plaga de langosta que por su número crecido amenaza con la destrucción total de las sementeras [milpas], y era de admirarse el entusiasmo y denuedo con que los ciudadanos procuraban el exterminio de tan terrible cuanto destructora plaga, pero desgraciadamente á poco tiempo de haberse principiado, la lluvia hizo suspender el combate [...] Hoy a las 2 de la mańana todos los vecinos de esta población emprendieron de nuevo la tarea, y a las nueve de la mańana se presentaron los informes. ${ }^{25}$

Aquí no se está hablando de recoger langostas muertas. Y el extraño horario nocturno para internarse en el campo no era para recoger la langosta muerta del gobernador. Lo que sucedía era que ni estaban obedeciendo órdenes, ni estaban recogiendo cadáveres. Estaban matando langostas vivas y voladoras. El horario era nocturno porque la langosta queda inmovilizada al atardecer, al descender la temperatura ambiental. Los insectos no pueden autorregular la temperatura de su cuerpo, y varía de acuerdo con la del ambiente. Así, por la noche, al descender la temperatura, baja su metabolismo y quedan inmóviles hasta que en la mañana, el sol y el aire los calientan y llegan a la temperatura que les permite recuperar el movimien-

${ }^{24}$ Eligio Ancona, op. cit., vol. 6, 1887, 335.

25 "Opichén", "Jefatura Política de Maxcanú", LUY, 75 (01/06/1883), 1, 2. 
to. Entonces vuelan. ${ }^{26}$ Lo más probable es que los campesinos no le hayan medido la temperatura a la langosta, pero sí tenían bien calculado que había que sorprenderla mientras estuviera paralizada, antes de que volara y se volviera inalcanzable.

En el mismo informe se dice que la "tarea señalada a cada individuo" era la de destruir dos almudes (entre 7 y $11 \mathrm{~kg}$ ) de langosta, pero el presidente municipal destaca que se sobrepasó con mucho lo estipulado. El día 26 se destruyeron siete fanegas y el 27 se quemaron in continenti otras 43. En total, las 50 fanegas podrían ser equivalentes a la carga máxima (considerando volumen y peso) que podrían cargar 50 mulas. ${ }^{27}$ Varias "sementeras", es decir, milpas, fueron devoradas y destruidas totalmente, pero el ánimo de la comunidad era fuerte: "No me cansaré de admirar el entusiasmo que reina en los habitantes de este municipio en la lucha contra los ortópteros puesto que concurren a ella hasta los más pequeños".

Evidentemente el pueblo, la comunidad, no estaba esperando órdenes del gobierno de Mérida. En Opichén la gente sabía que hacer, había tomado la iniciativa y se había organizado para enfrentar el grave problema en forma colectiva y autónoma. Lo que vemos es una sociedad civil vigorosa, que actuaba por cuenta propia sin esperar a que el lejano gobierno de Mérida, lento para visualizar y entender, ignorante y desfasado de los problemas del campo, les diera apoyo o tomara iniciativas. No necesitaban que nadie viniera a organizarlos. El gobierno iba detrás del pueblo y ni siquiera acababa de enterarse de las dimensiones del problema.

Pero en Opichén no todos se movieron en forma colectiva frente a la plaga. En ese municipio del partido de Maxcanú, había presencias lejanas, ausencias notorias que no eran, que no hacían parte de la sociedad civil y ni siquiera en momentos tan críticos como éste tenían

${ }^{26}$ Eudaldo Pereyra Cuevas, op. cit., p. 20; Ludivina Barrientos Lozano, et al., op. cit., p. $21-22,39-40$.

${ }^{27}$ De acuerdo con don Víctor Suárez Molina, el almud en el Yucatán del siglo xIX, era: "una de las medidas de más variada capacidad". En peso, su equivalencia variaba entre 3.5 y $5.5 \mathrm{~kg}$. Más adelante discutiré brevemente el problema de las equivalencias. Víctor Suárez Molina, La evolución económica de Yucatán. A través del siglo XIX, vol. 1, México, Ediciones de la Universidad de Yucatán, 1977, 100-101. 
interés en hacerse parte del colectivo que estaba en pie de lucha. Era el caso de uno de los henequenizadores más poderosos de esa década. Tal vez solamente había otro más poderoso y era su padre. Se trataba de "el digno Señor Don Eusebio Escalante Bates". Por esos tiempos, padre e hijo consolidaban su gran empresa "E. Escalante e Hijo" que era la casa exportadora de henequén más importante; representante de una línea de vapores que movía la fibra a Nueva York; importadores de equipo y maquinaria agrícola; participaban en los consejos de administración de líneas de ferrocarril y de bancos. ${ }^{28}$ Tenían más negocios, pero ya con esto se puede ver quién era ese "digno señor Don", que según nuestro reporte invirtió 400 pesos, "de su propio peculio", para exterminar al acrídido, pero: jsolamente en su finca! Mejor dicho, en una de sus haciendas henequeneras. En la llamada Calcehtoc. Aquí no entró el pueblo a dar la batalla colectivamente, ni de la hacienda salieron apoyos. Escalante manejaba su hacienda como territorio aparte. En medio de la plaga, Calcehtoc aparece sustraída, como si tuviera extraterritorialidad respecto de la sociedad civil. El digno Escalante no hacía parte del colectivo ni en tiempos de crisis. En Calcehtoc eran asalariados, en propiedad ajena, los que combatían la plaga. Aquí no entraba y no había sociedad civil. Era como una isla en el municipio de Opichén, sustraída de la comunidad, en aquel partido de Maxcanú que en ese año ocupaba un importante quinto lugar en superficie sembrada de henequén. ${ }^{29}$ Opichén se ve escasamente henequenizado. Creo que es así como hay que entender en aquel momento a la que luego se llamó "zona henequenera": como islas donde se había talado la gran diversidad que habita el monte para que sólo una especie viviera, sustraídas de la sociedad de los pueblos, destructivas de la comunidad, de la sociedad civil. Esta otra forma de enfrentar la plaga volverá a aparecer. Pero por lo pronto, ya aparecen las rupturas, las distancias y los diferentes lugares sociales de aquel tiempo.

${ }^{28}$ Raquel Barceló Quintal, "La oligarquía henequenera. Un estudio de caso: La familia Escalante", Tesis de Licenciatura en Antropología Social, Escuela de Ciencias Antropológicas, Universidad Autónoma de Yucatán, 1982, 101-110.

${ }^{29}$ Memoria que presentó el Ciudadano Gobernador del Estado de Yucatán, Octavio Rosado a la Honorable Legislatura, 1884. (1884) Anexo 18, Hemeroteca José María Pino Suárez, Mérida. 
Es interesante el resultado del combate al "dañino ortóptero" en Calcehtoc. El presidente municipal reportó que se habían "recogido más de 30 cargas de germen [huevos] del ortóptero" ${ }^{30}$ ¡Imagínense a treinta mulas cargadas, en fila, sacando bultos de huevos de langosta! Cada huevecillo mide de 5 a $7 \mathrm{~mm}$ de largo y tiene un diámetro de $1.5 \mathrm{~mm}$, son depositados en cápsulas que miden alrededor de $60 \mathrm{~mm}$ pero contienen los 60 huevecillos de cada puesta. ${ }^{31}$ Seguramente en esa hacienda había grandes extensiones de planteles de henequén joven, en "fomento". ¡Excelentes para ovipositar! La langosta que moría por todo el estado, era la langosta envejecida que había brotado a fines de 1882 y ahora cerraba su ciclo, unos 20 días después de haber depositado su "germen" en los terrenos que los henequenizadores le habían preparado. Un "germen" que los mayas conocían bien y que igual que los entomólogos contemporáneos, le habían puesto un nombre. Estaba inventariado en su saber como yal $s a k$, "cañuto de langosta" dijeron los frailes del siglo xvı. ${ }^{32}$

Y, ¿̇cuánto es eso de 30 cargas? Pues pueden ser $1,260 \mathrm{~kg}$ si tomamos en cuenta que la "carga común" en Yucatán, en el siglo XIX, equivalía a $42 \mathrm{~kg}$, a 24 almudes o a aproximadamente 55 lt (de áridos). Pero pueden ser menos. De acuerdo con don Víctor Suárez Molina, la carga tenía una "capacidad" elástica y comúnmente se le consideraba "equivalente a dos cajas o bultos de regular tamaño o lo que podía transportar a lomo una bestia". Así, había "carga de cacao" equivalente a $27.66 \mathrm{~kg}$; "carga de algodón", equivalente 14.72 kg. Creo que aquí, la "elasticidad" se explica precisamente por ser no sólo el peso que puede cargar, sino que se le puede acomodar a una bestia. Dicho de otra forma: cuando se habla de "cargas", se debe pensar en mulas cargando dos buenos bultos que pueden pesar hasta $42 \mathrm{~kg}$. La fórmula es: 1 carga = 1 mula bien cargada. Luego, en el caso del almud, don Víctor dice: "una de las medidas de más variada capacidad". En peso, su equivalencia variaba entre 3.5 y $5.5 \mathrm{~kg}$ y en volumen era "aproximadamente" 4.5 litros (de áridos). Pero gene-

${ }^{30}$ Véase nota 16

${ }^{31}$ Ludivina Barrientos Lozano et al., op. cit., pp. 35-36.

${ }^{32}$ René Acuña, Bocabulario de Mayathan, México, Universidad Nacional Autónoma de México, 1993, 438. 
ralmente se tomaba al maíz como referencia y la langosta tiene un volumen y un peso distinto. Lo tomaré así: $3.5 \mathrm{~kg}=1 \mathrm{almud}$. De esta manera, mi estimación es la mejor aproximación posible. La fanega era una medida de capacidad para áridos que equivalía a 12 almudes o aproximadamente 55 litros de áridos, lo que le da una equivalencia con la carga "común" que también equivalía a 55 litros. Pero también había fanegas específicas, como la "fanega de sal" equivalente a 26 almudes. Aquí, de nuevo, consideraré la fanega como equivalente a la carga porque se trata de langostas, saltones o huevos, es decir, de áridos. Finalmente hay que considerar que pudiera tratarse de cantidades mayores a las aquí calculadas. ${ }^{33}$

Sigamos ahora con la plaga en el partido de Maxcanú porque fueron llegando reportes. El primero de junio se mataron y quemaron 14 cargas y media de langosta en Chocholá. Para el día 15, se reportó que llevaban dos días invadidos, que ya habían devorado "la mayor parte de las sementeras de los alrededores del pueblo" y se habían matado y quemado 20 fanegas o 20 mulas bien cargadas de langosta que en una etapa de su vida llegó a comer su peso al día (1.5 gr). El 17 se informó que habían salido 216 personas de 12 a 60 ańos de edad, a las que se unieron el mayordomo y los sirvientes de la hacienda Kopobchacah, a recorrer el campo desde las 2:00 am hasta las 12 de mediodía a matar "saltonas hasta acabarlas". Una tarea que calificaron como fácil. Con lo que vemos dos cosas: Primero, no todos los hacendados se manejaban en la egoísta extraterritorialidad y en la falta de solidaridad de Escalante; y segundo, la nueva generación de langostas ya empezaba a brotar. ${ }^{34}$

En Mérida, el gobierno mandaba exhortos, felicitaciones, agradecimientos, daba ánimos, pero el combate estaba en manos y a cargo de la gente de los pueblos. El 15 de junio el gobernador les envía una circular a los jefes políticos: "Teniendo este Gobierno informes fidedignos de que la langosta continúa haciendo extragos [sic] en las milpas recientemente sembradas, las que destruye con demasiada

${ }^{33}$ Víctor Suárez Molina, op. cit., vol. 1, pp. 99-101.

34 "Jefatura Política de Maxcanú", LUY, 77 (06/06/1883), 2; 83 (20/06/1883), 3 ; 84 (22/06/1883), 3 . 
facilidad por ser muy tiernas; de nuevo recomienda a U. redoble sus esfuerzos y excite el patriotismo". Y el 27 de junio felicita en la primera plana del Diario Oficial: "El Gobernador ha apreciado debidamente la actividad y empeño con que las autoridades políticas y municipales han procedido [...] toda la sociedad yucateca ha aplaudido su conducta, y les está reconocida". ${ }^{35}$ Muchos aplausos para las autoridades que ciertamente parecen merecerlas, pero para el pueblo y la sociedad civil no hubo felicitaciones en los periódicos, a pesar de que las merecían. Tal vez, para el gobernador, la gente del pueblo no era una presencia, una realidad activa como si lo era para las autoridades locales. Sin duda, una de las dificultades del gobernador, a la hora de reconocer al conjunto de la sociedad, venía de la tradición cultural colonialista que la Independencia no suprimió. Una cultura que contenía (y aún contiene) una ruptura que en lo político no ha permitido reconocer cabalmente al pueblo maya ni como maya, ni como sociedad civil. La lengua de los reportes oficiales, el español escrito, distorsiona el panorama social, pues pinta a una sociedad castellanizada y homogénea. No era así y no está demás recordar aquí que según el censo de 1895, por todo el estado predominaban los hablantes "habituales" de lengua "indígena”, es decir maya; con la única excepción de los partidos de Mérida y Progreso donde (decían) predominaba el castellano. ${ }^{36}$ Pero claramente, en esta crisis, los mayas no necesitaban permiso para ser una sociedad civil activa, con iniciativa, organizada y vigorosa. ${ }^{37}$

35 "Gobierno del Estado", $L U Y, 81$ (12/06/1883), 1; "La langosta", $L U Y, 87$ (27/1883), 1; véase también: "La langosta”, $L U Y, 92$ (06/06/1883), 1.

${ }^{36}$ Dirección General de Estadística a cargo del Dr. Antonio Peñafiel, Censo General de la República Mexicana Verificado el 20 de Octubre de 1895, Estado de Yucatán, México, Oficina Tip. de la Secretaría de Fomento, 1899, 56.

${ }^{37}$ Utilizo el concepto de sociedad civil para referirme a la sociedad maya de los pueblos a sabiendas de que muchos seguidores de Gramsci no estarán de acuerdo. Lo que busco es destacar su calidad de sujetos políticos. Cierto que su forma de hacerse y de ser individuos, su subjetividad, su calidad política y su forma de construir el colectivo, era y es (como en todos los pueblos originarios) diferente a la de las etnias euroamericanas y dominantes. Por otro lado, entiendo que el concepto de sociedad civil fue creado en Occidente, para occidentales y por tanto los mayas nunca acabarán de caber en él. Pero en tanto construimos una nueva epistemología descolonial y para no guardar silencio y así presentar una imagen despolitizada/mutilada que niegue el carácter político de los mayas, paso a la desobediencia epistémica siguiendo el consejo de Mignolo (2010). Es solamente un mal uso temporal. 
Por fin, el 16 de julio, el gobierno manda a los jefes una circular donde: "Urge a organizar a la gente por secciones [en los pueblos] para que salgan cuando se avise de la langosta". Y, además exhorta a que "los interesados remuneren" a la gente..$^{38}$ Creo que detrás del llamado a "remunerar" y a que se organizaran por secciones en los pueblos hay que entender que la gente ya daba señales de cansancio cuando no de agotamiento y había que organizarse para salir en relevos. Así podrían recuperar fuerzas sin que el combate se desatendiera. El cansancio es consejero del desánimo y la destrucción de las milpas de los mayas daba amplio sustento al pesimismo.

Y otra vez, la gente de Opichén, Maxcanú, es la primera en organizarse por secciones. Pero: $¡$ dos días antes de que el gobernador emitiera esa recomendación y cuatro días antes de que se publicara! ¿Otra vez iba detrás el gobierno? El 14 de junio se reunió la Junta Municipal de Opichén, "para tratar exclusivamente sobre la manera más conveniente que se ha de adoptar para destruir el germen, las saltonas y las que andan destruyendo las sementeras". Acordaron nombrar a un vecino de 12 a 60 años que supiera leer y escribir para hacer una lista de su sección, de manera que apenas alguien avistara a las piceifrons, salieran dos secciones del poblado. También decidieron que si alguien las veía y no avisaba se le aplicaría una multa de dos a cinco pesos. ${ }^{39}$ Este reporte "parece" haberse traspapelado y no se publicó hasta el 6 de julio: más de 20 días después de que el gobernador recomendó la organización por secciones. No quisiera ser mal pensada, pero... El municipio de Opichén se ve muy interesante: la gente toma iniciativas, el jefe político no se apodera de los méritos de los presidentes municipales en los reportes sino que se mandan directo desde el municipio. Y vean las edades de quienes andan en la campaña: los nińos participaron, eran importantes y los tomaban en cuenta al diseñar la estrategia. Ellos sabían leer y escribir.

Pero si las acciones y las formas de enfrentar la plaga se conceptualizaban y se expresaban en lenguaje militar y hasta guerrero, en el partido de Ticul, la "campaña" tomó tintes militares peculiares por-

38 "Circular", LUY, 98 (18/07/1883), 2.

39 "Jefatura política de Maxcanú", LUY, 92 (06/07/1883, 2. 
que se trataba de un partido fronterizo en la geopolítica de la gran rebelión maya (1847-1901) que los no mayas llamaron "Guerra de Castas". ${ }^{40}$ Allá los soldados de la Guardia Nacional participaron en el combate a saak'. El 27 de junio el jefe político reportó que: "La paz pública en este partido sirve al presente para perseguir tenazmente a la langosta que acaba de aparecer, hasta lograr exterminarla en su totalidad". Luego, el presidente municipal de Ticul hizo una interesante mezcla de estilos en su reporte pues primero adoptó un tono marcial para luego rayar en la cursilería de un cronista de eventos sociales: "la cooperación de los jefes del Batallón de la Guardia Nacional de este partido ha hecho marchar la madrugada de hoy [...] sobre quinientos hombres a matar langosta [...] entre estos brillaba el entusiasmo de la juventud más acomodada de esta ciudad". ${ }^{41}$ Cursilería afortunada, porque nos muestra la diversidad social. Aquí los "más acomodados" sin duda tenían una distancia social con el resto de la gente del pueblo, pero finalmente hacían parte de él. Marchaban juntos. No se movían en la extraterritorialidad de los Escalante ni en el desfase del gobierno de Mérida.

El 27 de junio, de Izamal se informó de un nuevo agravio: ¡saak' devoraba las casas! "Ya las está destrozando", dijo el jefe político. ${ }^{42}$ Construida con 45 especies de plantas diferentes y sin clavos, la casa maya no se ve apetitosa, pero no escapó a su voracidad. ${ }^{43} \mathrm{Y}$ el 30 , desde Temax parece que ya se perdía la esperanza. Después de perder sus casas, sus milpas y todo su grano de reserva, la sensación era de derrota:

Ha destruido en su totalidad [...] las sementeras [...] en casi todos los pueblos se habla [...] de [su] imposible destrucción, a causa de su abundancia, y no se oyen más que lamentos de los labradores que han abandonado sus

${ }^{40}$ Véase Don E. Dumond, The Machete and the Cross. Campesino Rebellion in Yucatan, Lincoln, University of Nebraska Press, 1997; Marie Lapointe, Los mayas rebeldes de Yucatán, Mérida, Maldonado Ed., Gobierno del Estado de Yucatán, 1997; Nelson Reed, La Guerra de Castas de Yucatán, México, Era, 1971.

41 "Jefatura Política de Ticul", $L U Y, 92$ (06/07/1883), 2.

42 "Jefatura Política de Izamal", $L U Y$, 87(27/06/1883):1.

${ }^{43}$ Lourdes Villers Ruiz, Rosa María López Franco, Alfredo Barrera Marín, "La unidad habitación tradicional campesina y el manejo de recursos bióticos en el área maya yucatanense", Biótica 6, 3, 1981, 293-323. 
sementeras, habiendo consumido todas sus semillas inútilmente, después de 3 o 4 siembras agotadas sucesivamente; siendo el estrago [tal] que se ha dado el caso de que se introduzcan en algunas casas que han tenido que dejar forzosamente sus habitantes, después de varios esfuerzos por desalojarla. ${ }^{44}$

El 6 de julio, se informa que en Ticul, "ha devorado cuanto ha encontrado", y el jefe hace una mención "especial" del "patriotismo, actividad, abnegación” de los de Tekit y Mama porque aportaron doscientos pesos para "proveer a los indigentes que marchan persiguiendo a larga distancia al destructor acridio". Sin duda ya había muchos pobres sin milpa y sin semilla y muy necesitados de efectivo para conseguir su comida. También dice que en Mérida empezaba el desabasto: "ya va sintiéndose la escasez de grano". ${ }^{45}$

En Peto, el gran partido del sur, granero de Yucatán, frontera y también territorio de los mayas "bravos" rebeldes de la "Guerra de Castas", reinaba la desolación desde el 14 de julio: 1,470 ha de milpas devoradas y 400 cargas de langosta recogidas. Parece que el jefe no pudo juntar los ánimos para abundar y solamente envió unas líneas que parecen salir del fondo de un corazón pesado: "Tengo el sentimiento de comunicar a Ud. que continúa plagado este partido de langostas las cuales han consumido ya en su mayor parte las sementeras de maíz [...] reservándome dar cuenta de las que se vayan destruyendo". 46

Del lado rebelde, de los mayas seguidores de la cruz oracular que dirigía la rebelión maya, ${ }^{47}$ obviamente no hay reportes. Pero su situación, las condiciones y sus problemas con la langosta seguramente eran afines a los que vivían los habitantes del partido de Tizimín. $\mathrm{Al}$ principio hubo un breve espacio para el optimismo, pero luego, en las altas selvas, aparecieron otros problemas:

44 "Jefatura Política de Temax", LUY, 92 (06/07/1883), 2.

${ }^{45}$ J.T.F., "La langosta”, LRM, 443 (06/071883), 2; Jefatura Política de Ticul", LUY, 94 (11/07/1883), 3; y 98 (18/07/1883), 2.

46 "Jefatura Política de Peto", LUY, 99 (20/07/1883), 3.

${ }^{47}$ La cruz mesoamericana tiene unos 3000 ańos de antiguedad, véase Miguel Ángel Astor-Aguilera, The Maya World of Communicating Objects: Quadripartite Crosses, Trees, and Stones, Albuquerque, University of New Mexico Press, 2011. 
es tal su número, es tal la extensión que tiene invadida y relativamente exigua la población del partido que temo sean estériles los mayores esfuerzos. Otra razón estorba la destrucción de la langosta: acampada en medio de dilatados y elevados bosques, apenas consumen una sementera se refugia perseguida, en las altas copas de los árboles y allí descienden luego a devorar las renacientes plantaciones. ${ }^{48}$

El jefe político de Tizimín era repetitivo: "las largas distancias de los puntos invadidos no me permiten organizar gente para la destrucción del acridio". ${ }^{49}$ Los seguidores de la cruz también vivían en comunidades dispersas. Ellos, como los tizimileños, no hacían su milpa entre los limpios planteles de henequén joven, sino que la hacían conforme a la antigua tradición: entre los montes altos que ellos cuidaban y que todavía abundaban en el sur. Monte que no es un ambiente adecuado para la gregarización de la langosta, pero que una vez convertida en plaga, presentaba problemas adicionales porque podía pasar las noches a salvo, en las copas de los árboles; y porque para perseguirla había menos gente, distancias más largas y selvas densas que atravesar. Incluso, el 3 de julio del 1883, vemos que los del bando $d z u l$ (extranjeros o no mayas) necesitaban tiempo y hombres. Ese día empezaron a regresar a Tizimín los reclutas que servían en las colonias militares para la defensa contra los rebeldes que la prensa llamaba "bárbaros". ${ }^{50}$ Se necesitaba de todos para enfrentar la plaga.

Pero en Tizimín también se cultivaba un poco de henequén. $Y$ aunque las exportaciones de fibra no frenaron su crecimiento global, el agave de aquel partido sí fue devorado junto con todos los demás cultivos. Del municipio de Panabá llegó un reporte muy gráfico el 24 de junio: "no existe una sola milpa sembrada y no sólo destruyen las plantas tiernas de maíz, sino hasta el henequén [...] parece que en lugar de disminuir van en aumento con mucha rapidez [...] ha destruido por completo por segunda y tercera vez las

48 "Jefatura Política Accidental de Tizimín", LUY, 92 (06/07/1883), 3.
49 "Jefatura Política Accidental de Tizimín", LUY, 85 (23/06/1883), 3.
50 "Jefatura Política Accidental de Tizimín", LUY, $92(06 / 07 / 1883), 2$. 
siembras de maíz [...] la caña y la yuca". ${ }^{51}$ El 2 de julio, el jefe habla de la forma colectiva en que se tomaban las decisiones: "cité al vecindario a junta popular [...] anoche, deseando que la determinación que se tomara tuviera el apoyo moral de toda la sociedad tizimileña" ${ }^{52}$ Otra vez, la sociedad civil y al igual que en Opichén: las iniciativas no surgen del gobierno de Mérida. En medio de aquella apremiante crisis, autoridades y pueblo hacían los espacios para tomar decisiones colectivas. Es difícil pensar que fuera algo improvisado, seguramente había una sólida tradición.

Pero la destrucción de las milpas empezó a orillar a algunos a otras tareas que les permitieran ganar dinero para comprar alimentos. El jefe de Tizimín no dice cuáles eran esas "actividades remuneradas" sólo señala que ha tenido:

que retirar a los menesterosos [...] por tener que ocuparse en trabajar para ganar el maíz para su indispensable sustento, [y] siendo poco poblado además [el partido] no se extermina más langosta. La voladora parece dirigir sus nubes hacia el oriente, pero la saltona aparece ya en incalculables cantidades.

Pidió disculpas por lo poco logrado, pero eso sólo revela la frustración, el sentimiento de impotencia frente a aquella desmedida infestación. Para el 6 de julio reportó 338 cargas de langosta y 15 almudes de "larva" en todo el partido, con excepción de "las fincas" que "no avisan"; del día 9 al 13, fueron 582 cargas y 9 almudes; y al día 18 agregó 157 cargas de "langosta crecida" y otras 60 de "saltones", siempre sin reportes de las fincas. Aún así, en ese mismo reporte del 18 de julio, encuentra un lugar para el optimismo:

Pláceme [...] que por lo pronto, la casa mercantil M. Arce y Hno. piden ya la primera partida [de maíz] que se proponen expender sin utilidad alguna, puesto que la escasez de capitalistas impiden toda asociación protecto-

${ }^{51}$ La yuca es un tubérculo que crece sobre la tierra. "Jefatura Política Accidental de Tizimín”, LUY, 92 (07/06/1883), 2.

52 “Jefatura Política Accidental de Tizimín”, LUY, 94 (11/07/1883), 3. 
ra con ese fin y que el $\mathrm{H}$. Ayuntamiento, sin fondos, apenas puede cubrir sus indispensables gastos. ${ }^{53}$

Ojalá. Me gustaría mucho pensar que esto es verdad. Que los hermanos Arce en efecto, vendieron maíz "sin utilidad alguna". Pero... los mercaderes no fueron sacados del templo por altruistas. Tal vez esa declaración fuera parte de un juego político: era un respaldo al gobernador y una bofetada con guante blanco a los comerciantes de Mérida que ya vamos a ver en el esplendor de la insensibilidad. Lo que sí les puedo asegurar es que el hambre empezaba ya a asomar su horrible cara. Es tiempo de encararla y de enfrentar al Estado. El que se escribe con mayúscula, el que según Gramsci está integrado por todos aquellos que ejercen la hegemonía y otros replican que sólo la pretenden pero no la logran. Bueno, pues esos, aquí y ahora son los del gobierno más los grandes hacendados y comerciantes y me parece que a la hora del hambre, los últimos la ejercieron y fue para mayor desgracia de los campesinos milperos que perdieron todo. Pero hay algo más, y es que entre los del gobierno estatal y los grandes hacendados/comerciantes/henequeneros había un enfrentamiento, una pugna que se tensó en el peor momento y se jugó alrededor del control de los alimentos.

A la hora de la plaga los hacendados/comerciantes estaban enojados con el gobernador Octavio Rosado: él estaría suavizando la situación. Estaban rabiosos. Rosado se había atrevido a enviar al Congreso del Estado la iniciativa de aplicar un impuesto a jtodo el henequén que se introdujera desde el interior del estado al Puerto de Progreso! Los diputados locales lo habían aprobado el 30 de noviembre del pasado 1882. Los grandes exportadores se movilizaron y buscaron amparos en todas las instancias sin conseguirlo: desde los tribunales locales hasta la Suprema Corte de Justicia. El asunto desbordó el ámbito local y fue motivo de polémicas y debates públicos en los periódicos de la ciudad de México. Intervinieron personajes con categoría de prócer como Justo Sierra Méndez, quien desde su

53 "Jefatura Política Accidental de Tizimín", LUY, 95 (13/07/1883), 2; 99 (20/07/1883), 2, 3 . 
periódico La Libertad, defendió a los exportadores e Ignacio L. Vallarta quien los atacó. Ganó Rosado y siete meses después, el lunes 4 de junio de 83, cuando las notas sobre la plaga empezaban apenas a invadirlo, La Unión Yucateca, Periódico Oficial del Estado Libre y Soberano de Yucatán, anunció la decisión final de la Suprema Corte y proclamó el triunfo de "la soberanía de Yucatán". Entre los que pelearon contra el impuesto, estuvieron - but of course- los Escalante a través de su casa comercial "E. Escalante e Hijo", Manuel Dondé, "M. Ponce y Ca.", "C. Cámara e Hijos”, "Ibarra y Ca.", Manuel Zapata Bolio. ${ }^{54}$ Más de un mes después del último fallo, hasta la primera quincena de julio, La Unión Yucateca seguía regodeándose con el triunfo de Rosado y metiendo el dedo en la llaga de los hacendados.

Fue por el 14 de julio, que se abrió el juego. Se publicaron las notas donde se puede ver que la plaga y la miseria de la gente fue la arena en la que le dieron continuidad a su pleito. El segundo round fue una autoderrota moral: lo volvieron a perder los hacendados. Bien, pues ese día 14, en la página dos de La Unión Yucateca, otra vez se machacó lo del impuesto y junto a esa nota se hizo pública una invitación que el gobernador dirigió a seis "señores" por "sus sentimientos altamente humanitarios", para integrarse en "Junta" de apoyo a los necesitados por la plaga. Estaba firmada por él y fechada el 5 de julio. La publicación fue claramente una forma de exhibirlos y ponerlos en evidencia.

Comprendiendo este Gobierno que al Estado le amenaza una verdadera calamidad, con motivo de los extragos [sic] que hace en las sementeras [milpas] la langosta [...] y comprendiendo [...] que es urgente prevenirse contra las consecuencias de ese peligro; confía en el patriotismo y sentimientos humanitarios de U. [...] para que reunidos y organizados en Junta, procedan desde luego a escojitar los medios de colectar una cantidad suficiente para la compra de granos; a fin de que en un caso de escasez absoluta ó de un precio que no esté al alcance de la clase menesterosa, se

${ }^{54}$ LUY, 76 (04/06/1883), 3; 80 (13/06/1883), 1, 3; 84 (22/06/1883), 1, 3; 93 (09/07/1883), 1, 2, 4; 96 (14/07/1883), 2; Decreto del 30 de noviembre de 1882; Orden de 28 de diciembre de 1882, en Eligio Ancona,, vol. 6, op. cit., pp. 300-306. 
acuda a las necesidades [...] en la inteligencia de que este mismo gobierno contribuirá al efecto con la misma suma proporcionada [...] con [etc., etc.] mi particular aprecio. ${ }^{55}$

Entre los elegidos estaban los hacendados exportadores: Manuel Dondé Cámara y Manuel Zapata Bolio, ambos pelearon el amparo y eran muy cercanos a Escalante; Eulogio Duarte; Gregorio Milán; Juan Miguel Castro, fundador del Puerto de Progreso y gran promotor de la exportación de fibra quien sin ser de los grandes, hacía cabeza moral de un grupo enfrentado con los afanes de Escalante por controlar toda la exportación del henequén; y Benito Aznar Pérez, de quien volveremos a oír.

Y resulta que no aceptaron. El rechazo fue colectivo. Pero si la negativa de estos ricos comerciantes y henequenizadores (sin lugar a dudas: consultada y consensada con otros ricos hacendados) a buscar fondos para ayudar a la gente a la hora del hambre suena indignante, sus "razones" y su propuesta lo son aún más. Se publicó en el mismo número del sábado 14 de julio, justo debajo de la invitación del gobernador y de una circular donde el gobierno daba a conocer los nombres de los caritativos negativos: "La honrosa distinción que implica el nombramiento [...] nos ha obligado a meditar con toda calma y consultarle lo mejor y más práctico [...] Si nos hubiésemos dejado guiar por el noble impulso que sin duda motivó la comunicación desde luego habríamos aceptado tan honorífico nombramiento".

Sus "meditaciones" los llevan a proponer algo que resulta difícil de calificar:

La más amplia libertad para las operaciones mercantiles, buscando así la competencia es en todas circunstancias y especialmente en las de escasez de granos o de artículos de primera necesidad, según tiene comprobado la experiencia, el medio más adecuado para evitar a los pueblos los horrores del hambre. Dejar libre, al espíritu comercial, da mejores resultados para el pueblo necesitado. ${ }^{56}$

55 "República Mexicana”, $L U Y, 96$ (14/07/1883), 3.

56 "Respuesta", LUY, 96 (14/07/1883), 3, 4. 
Su propuesta incluye: primero, "libertad al comercio"; segundo, exención de "cualquier" impuesto federal y estatal al maíz. Los señores claramente querían llevarse la maleta del tesoro ahora que todo el alimento tendría que ser importado. Pero si ya antes de la plaga, los campesinos difícilmente tenían con que pagar, ahora que estaban arruinados: ¡menos! Por eso pedían también que, en caso de que esas "prácticas" medidas no funcionaran, el gobierno estatal pagara una prima a los comerciantes importadores de maíz. ¡La cosa era enriquecerse con el hambre de la gente! Adam Smith nunca imaginó seguidores tan cínicos. Argumentaron que en caso de regalar maíz, no habría dinero que alcanzara y se desalentaría la importación. Además, y a su modo, se pusieron antiyankis : "Esa cantidad de maíz tiene que representar a nuestro juicio muchos cientos de miles de pesos que pasarían al mercado americano". Estaban respirando por la llaga que les abrió el impuesto al henequén: si el gobernador les quitaba parte de sus ganacias henequeneras con impuestos, ellos las recuperarían por la vía del hambre de la gente. Sin duda estaban convencidos de que el gobierno se haría de una fabulosa fortuna con el famoso impuesto. Y si Rosado quería cobrarles, que se las viera con sus propios recursos.

Rosado les dio dos respuestas a los caritativos. La primera fue directa y para que nadie, ni los historiadores, perdiéramos detalle, se publicó en el mismo periódico, el mismo sábado. Les dijo que estudiaría su respuesta: "pensando muy principalmente en [...] la clase menesterosa, digna por mil títulos a la consideración de todo gobierno". ${ }^{57}$ Les pidió que "guiados por su notorio patriotismo" le siguieran pensando. Sobre la exención de impuestos y la prima a la importación de maíz, les aseguró que el gobierno no contaba con ingresos para subsidiarlos pues ni siquiera podía enfrentar los gastos de su propia administración. Cosa que sin duda los comerciantes tiraron a la basura como demagogia barata. Pero el gobernador hizo algo más. El 20 de julio, entre las toneladas de langosta exterminada y quemada, publicó en la primera plana del Diario Oficial una lista de los comerciantes que habían recibido sacos de maíz a

57 “República Mexicana”, LUY, 96 (14/07/1883), 4. 
bordo del vapor British Empire que recién había llegado. La nota iba al centro, en letra grande y, en esos momentos de hambre, se intitulaba: "Importación de maíz". De entrada se destaca que: "buena cantidad de maíz recibió el comercio de Mérida". En total llegaron 21,900 sacos. Escalante 1,400; Zapata 500; Dondé 5,800; Peón 600; Ibarra 100; Cámara 200; Aznar 200; Cámara 1,000.58 No se puede decir de cuántos kilos era entonces cada saco de maíz, pero actualmente lleva 80 kilos. Cada uno recibió varias toneladas de maíz.

La Revista de Mérida y El Eco del Comercio, así como algunos diputados, siguieron insistiendo en la derogación de los impuestos no sólo al maíz, sino al arroz y al frijol, y a través de La Unión Yucateca el gobernador les aseguró que haría todo lo posible ante la federación pues el maíz, aclaró, no causaba impuestos estatales. Y a continuación esos "caritativos" hacendados, se organizaron en "Junta" y también aportaron fondos propios, pero no para ayudar a la gente, sino para combatir la plaga en su territorio: para defender su henequén, su mercancía.

Para calibrar y poner en perspectiva las intrigas que agitaban los palacios y las casonas de Mérida, vamos a los reportes de los partidos de Mérida y Motul. En ese momento ya estaban fuertemente henequenizados y posteriormente serían conocidos como "el corazón" de la llamada "zona henequenera". Allí el pueblo no parece lanzarse al combate de la plaga como en los otros lugares. Sí sale, pero las cosas son diferentes.

El primer reporte del jefe de Motul llegó fechado el 12 de junio. Fueron 200 hombres los que salieron por dos días a "expedicionar en las inmediaciones de esta ciudad" (Motul). Lograron matar y quemar "en lugares convenientemente situados fuera de la población 130 cargas de langosta". Pero, "habiéndose abonado [...] 75 centavos a cada individuo por carga”. Aquí el trabajo no había sido voluntario, aquí iba ipagado! Se habla del apoyo de los pueblos y también de los hacendados que "contribuyen de su peculio". El jefe político habla mucho de los daños pero siempre son "sementeras"

58 “Importación de maíz”, LUY, 99 (20/07/1883), 1. 
(milpas) las dañadas, y nunca "planteles" (sembrados de henequén) aunque ya sabemos y hemos visto que las piceifrons también cargaban con el agave. Acá, en la región henequenizada, el insecto se volvió extrañamente selectivo y solamente anduvo: "destrozando con furor inaudito sus sementeras de granos de primera necesidad". Para el día 20 de junio, las "sementeras de cereales [estaban] reducidas a un décimo". Y además de reportar 1,045 cargas quemadas por todo el partido (del 12 al 19 de junio), reporta que se agotaron los 348 pesos del "fondo de donaciones" para: "retribuir con 75 centavos por carga que ha presentado cada individuo, cuya retribución es un aliciente para que nuestra clase menesterosa se afane" ${ }^{59}$ Esto es inédito: ¿pagar para que la gente "se afane"? Después de todo lo visto en los otros partidos, ¿dónde está la sociedad civil? ¿Ustedes creen que la gente se iba a sentar a mirar cómo la langosta devoraba sus milpas y no se iba a movilizar a menos que les pagaran? Probablemente, el jefe político de Motul no nos está dando el panorama completo, aquí hay un entrelineado que entresacar.

El jueves 21 de julio, el ayuntamiento de Motul, cabecera del partido, levantó un acta dando un "voto de gracias" al jefe político por "su actividad y empeño" en la "destrucción" y porque promovió: "suscriciones $[s i c]$ que ascendieron a más de $\$ 600$, contribuyendo él como el que más de su peculio [...] notándose ya casi la completa desaparición de la langosta". ${ }^{60}$

Si la langosta desaparecía era porque su ciclo se cumplía, venía la nueva generación de saltonas y para la semana siguiente, del día 20 al 29 de junio, destruyeron 1,225 cargas de langosta y "saltones" sin incluir datos de las fincas. Además el jefe se adornó consiguiendo otros \$711.38 de "suscrición" en la ciudad de Motul. En Motul sí había dinero, era del henequén y había un gran apremio por defenderlo. Se reforzó el optimismo: "se ha despejado [...] cada uno acaricia la esperanza de que la calamidad no será tan terrible como se creyó al principio [...] en este partido no se encuentra una sola langosta [...] y apenas uno que otro manchón de saltones". ${ }^{61}$

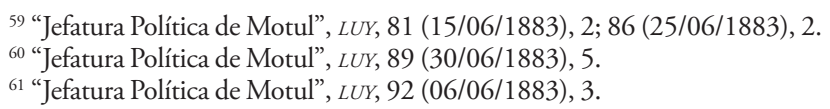


Entre el 1 y el 8 de julio agregaron otras (impresionantes) 618 cargas. Y ese día se reporta que regresaron a Motul, a sus pueblos, los hombres del partido que habían sido reclutados para servir en la Guardia Nacional en las Colonias Militares de Oriente. Llegaban refuerzos para combatir a saak. ${ }^{\prime 2}$ En estos reportes el jefe no habla sino de las "sementeras", de las milpas. No dice nada de los "planteles", que es la forma de referirse al henequén. También aclara que no reporta información de las "fincas", que era donde se cultivaba el agave. Pero de los daños al henequén, las cifras sobre las exportaciones crecientes nos pueden ayudar para hacernos una idea de cuánto afectó. Ayudar, porque no sería nada raro que las cifras oficiales contengan una importante subestimación. Éste era el primer año en que el gobernador iba a aplicar el impuesto y de seguro muchos hacendados encontraron la forma de sacar la fibra de henequén por puertos menores, sin reportarlo a la aduana de Progreso y sin pagar el impuesto. Como fuera, la langosta se vio inapetente con el henequén de la zona henequenera porque de 24,244.174 ton exportadas en 1882, subió a 32,651.597 ton en 1883 y las cifras oficiales volvieron a reportar un significativo aumento a 42,043.070 ton en $1884 .{ }^{63}$ Recuerden que el henequén requiere siete ańos para madurar y el aumento en la exportación refleja que nuevos "planteles" entraron en explotación. "Planteles" que (milagrosamente) habían logrado proteger de la plaga en 1883. Ha quedado claro que la langosta arrasó con el maíz, la caña de azúcar, las casas de campesinos y hasta con el henequén de Tizimín, pero algo la volvió inapetente frente al henequén en la zona de las grandes haciendas. Parece que el de Motul se logró salvar. Vamos al partido de Mérida.

En el partido de la capital se puede ver la ruptura social, se ven dos sociedades con dos estrategias. Se comenzará por el pueblo milpero en el partido de Mérida, vecino de Motul, donde la infestación de ninguna manera fue menor o más moderada. El reporte lo escri-

\footnotetext{
62 “Jefatura Política de Motul”, LUY, 95 (13/07/1883), 2.

${ }^{63}$ Gonzalo Cámara Zavala, "Historia de la industria henequenera hasta 1919", en Enciclopedia Yucatanense, tomo III, México, Gobierno del Estado de Yucatán, 1977, 778.
} 
bió el 13 de junio el juez de Papacal de Sierra, un pequeño pueblo situado al norte de la ciudad de Mérida:

El domingo como a las dos de la tarde una gran nube de langostas se extendía desde á una legua de distancia de este pueblo por el norte, hasta dos leguas al oriente [poco más de $12 \mathrm{~km}$ y medio], ocultando la luz del sol; y media hora después fueron cayendo hasta cubrir enteramente el piso: por cuyo motivo mandé exterminar a tan terrible plaga, y que ese mismo día, hasta ya entrada la noche, con la muy poca gente que reuní, se destruyeron 2 fanegas, y como á las cinco de la mañana del día siguiente todos los habitantes de ambos sexos de este pueblo ya estaban con el afán de extinguir o mitigar en parte la plaga, consiguiendo destruir 8 fanegas hasta las nueve de la mańana que emprendieron el vuelo. Es lo que ha ocurrido en este pequeño pueblo. $^{64}$

Parece que estamos frente a un pueblo deshabitado, casi fantasma. Entre "todos los habitantes" y con "afán", apenas acabaron con 10 fanegas o cargas... La sociedad civil disminuye mientras los asalariados, los que cobran por combatir a la plaga, aumentan. Predominan. En 1883, bajo la carga de saak', los partidos de Mérida y Motul ya eran diferentes al resto del estado. Era otro lugar social: muy distinto a Opichén y aun a Tizimín.

Pero en el partido de la capital no todos se reunían y organizaban para la acción directa. En la ciudad capital sí se organizaban para el combate, pero en juntas de salón, muy lejos de saak. El 13 de julio, el ayuntamiento de Mérida envió un reporte a la jefatura política donde informa que el municipio está invadido y se ha ensañado sobre "el maíz". Estaban preocupados porque podía extenderse a "la caña dulce y el henequén, que son la riqueza y vida de nuestro país" ${ }^{65}$ Pero, ¿eran la "riqueza y vida" del "país"? ¿O de unos cuantos? ¿Y la milpa, por la que la gente se "afanaba" tanto en el resto del estado, no era riqueza? ¿Por qué ese violento ninguneo, esa tachadura de la diversidad de maíces, frijoles, calabazas, tomates, chiles, tubérculos y demás

64 "Estado de Yucatán.- Jefatura Política de la Capital", LUY, 81 (15/06/1883), 1.

${ }^{65}$ Jefatura Política de la Capital”, “Junta”, LUY, 97 (16/07/1883), 1. 
plantas de ese policultivo que es la milpa maya y que por siglos había alimentado no sólo a los mayas, sino también a los colonizadores en esta inmensa laja que es la península de Yucatán? La fuente histórica de la alimentación en la península, ¿̇no era "riqueza y vida”?

Para los henequenizadores, era un freno, un obstáculo "al progreso". O, mejor dicho: a su progreso. Mientras los hombres y las mujeres mayas tuvieran su milpa, tenían autonomía. Tenían lo que querían y necesitaban, lo que le daba sentido a su vida, lo que les daba su ser y los hacía personas (mayas). Los henequenizadores no necesitaban eso. Ellos no necesitaban gente, ellos necesitaban "brazos". Para cortar la penca del henequén y desespinarlo en campo, transportarlo a la casa de máquinas, rasparlo para sacar su fibra, asolearla y secarla, convertirla en pacas y llevarla al ferrocarril. Cada vez necesitaban más brazos. La langosta estaba dejando a la gente sin alimentos y sin semilla para resembrar. Y los del henequén la estaban usando para que les hiciera el trabajo sucio. Por eso no iban a regalar maíz. Iban a convertir al milpero y a su familia en asalariados, en mercancías por la vía del hambre. Además, usando las ganancias de la exportación de henequén, iban a importar maíz, para convertir en mercancía también, al "Santo Gracia", al Santo Elote, o, como le dicen tanto al grano como a la Virgen María: Mamá Xunáan (Señora Madre), X-K'íchpan Xunáan (Sabrosa/Hermosa Señora). ${ }^{66}$

Pero la langosta no destruyó la milpa. Comió milpas y la gente se quedó a merced de los lobos. Fue la respuesta social orquestada por los henequenizadores la que llevó a la destrucción de la milpa por el norte del estado, por la que sería conocida como "zona henequenera”. Es que la milpa, no es solamente un espacio agrícola es también el espacio a partir del cual los mayas han construido su propia subjetividad, su relación con las personas, con la naturaleza y con lo sagrado. El lugar y el quehacer que le da sentido a la vida de las y los campesinos mayas. Y fue destruida por los henequenizadores utilizando a saak' como dice el eufemismo: ¡cómo motor de la historia! Ellos utilizaron la crisis, la plaga, el hambre, el agotamiento y la

\footnotetext{
${ }^{66}$ Santiago Domínguez Aké, La milpa en Muxupip, México, Letras Indígenas Contemporáneas, Dirección General de Culturas Populares, 1996, 138.
} 
desesperación de la gente para destruir no solamente un cultivo sino una cultura, un ecosistema, un mundo: el alma, los corazones de muchos hombres y mujeres. La rica diversidad de las selvas del norte fue talada para que sólo el agave fourcroydes, una sola especie, viviera. Esas selvas eran lo que podríamos llamar "las condiciones materiales" de la producción milpera. Y, digo "podríamos" porque en realidad el concepto resulta estrecho y reduccionista pero no tenemos en nuestra lengua europea, en nuestros saberes occidentales, un concepto que una los aspectos y elementos físicos y metafísicos que son condición para la milpa maya. El k'áax o monte (selva) de los mayas es un lugar habitado por plantas, animales, piedras, nutrientes y también por sonidos, "aires", vientos, seres sagrados o solamente sobrenaturales.

En una palabra, la respuesta de los henequeneros ante la plaga fue concebida y ejecutada para romper una historia. No fue la langosta en sí, sino la forma en que se respondió socialmente a ella lo que destruyó no sólo la milpa sino a los milperos mismos en las haciendas henequeneras. Fue la falta de solidaridad humana, la perversa respuesta de los hacendados a esa magna crisis, a ese cataclismo, lo que destruyó la milpa.

Por el sur, por el oriente, los milperos la pasarían muy mal, algunos habrán ido al norte, a las haciendas. Pero tenían opciones. La langosta era parte de su historia y el riesgo estaba contemplado en la estrategia milpera. Dentro de sus milpas habían sembrado una buena cantidad de tubérculos, que crecen bajo la tierra, a salvo de saak'. Don Marcelino Tun Canul, milpero de Xocén explica que,

Si un campesino no tiene mucho maíz, pero si tiene makal (Xanthosoma yucatanense) no es pobre, porque con el poco maíz que tiene, lo puede mezclar con el noyo [pulpa] del makal para aumentar más la masa. Así no tiene que comprar maíz en la tienda. Es por eso muy necesario sembrar makales en las milpas.

Y, don Fulgencio Noh Dzib relató que: "Cuando yo era niño de seis años había escasez de maíz por las langostas. A cada niño le dieron dos tortillas [hechas con camote molido y mezclado con la masa de 
maíz]. Las personas iban a las milpas abandonadas en busca de camote (ipomea batatas)" ${ }^{67}$

Pero en el norte, en la zona henequenizada, esta opción se había cancelado porque una estrategia empleada para abrir los campos al henequén consistía en darlos para milpa uno o dos años y luego sembrar el agave, con lo cual, los tubérculos, que siguen creciendo hasta por cinco y más años, se perdían.

\section{PARA CONCLUir}

Así que mientras en los salones de Mérida se discutía angustiosamente (sin duda) el problema de la langosta y se hacían colectas y se calentaban los revanchismos políticos, en el campo la gente seguía sin dormir, madrugando, luchando por su vida. ¿¿Qué es caminar debajo de una de esas gigantescas nubes de langosta que cubren leguas de cielo? Para empezar déjenme decirles que las langostas digieren mientras vuelan, y son miles las que integran una manga. Es como andar bajo una cerrada e intensa granizada. Duele, golpea fuerte. Es moverse envuelto en los ruidos crispantes que hace al volar. Todo eso bajo un cielo oscurecido y sabiendo que el peligro se cierne. Es correr a buscar el refugio de un árbol, que con toda su solidez milenaria puede perder sus ramas, su follaje, su calidad de refugio en unos minutos. ${ }^{68}$ Parece que lo mejor sería correr a meterse en casa. ¿Cuáles fueron los sentimientos, las sensaciones de la gente cuando la langosta devoró sus casas? ¿Qué hay en el corazón de las personas cuando miran a su familia en esa zozobra y ya no queda lugar para refugiarse? ¿Habrán corrido a buscar refugio en las cuevas? Posiblemente se fueron a refugiar en las grutas subterráneas donde se abren los cenotes, no solamente buscando un techo, sino agua. El agua para beber, para cocinar, para bañarse, también se volvió un problema porque saak' cayó en pozos y cenotes y ahí se

\footnotetext{
${ }^{67}$ Silvia Terán, Christian Rasmussen y Olivio May Cauich, Las plantas de la milpa entre los mayas, Mérida, Fundación Tun Ben Kin, A. C., 1998, 161-163, 170.

${ }^{68}$ Me basé en la descripción que hace Rodolfo Barreiro, agente de la Secretaría de Fomento que fue a investigar la plaga en Veracruz en 1883. "Secretaría de Fomento", $L U Y$, $112(13 / 08 / 1883), 1$.
} 
pudrió y contaminó el agua. ${ }^{69}$ La gente tuvo que recurrir al "agua de los pájaros" que es la capa superficial de los cenotes. ${ }^{70}$

Sin milpa, sin semilla, sin granos de reserva, sin casa, sin cosechas para vender, sin agua para beber... necesitaban ayuda, necesitaban tiempo para recuperarse y volver a la milpa. Pero... la hacienda henequenera no se los iba a dar porque al perderlo todo se habían convertido en el sueño dorado de los henequenizadores. Ellos sí tenían maíz. Lo importaban con las ganancias de la exportación de fibra y querían que la gente viviera en, por y para la hacienda. Para su hacienda. Y la gente tuvo, y lo subrayo: tuvo que ir a la hacienda.

\section{HEMEROGRAFÍA Y MANUSCRITOS IMPRESOS}

Acuña, René, Bocabulario de Mayathan, México, Universidad Nacional Autónoma de México, 1993.

Arzápalo Marín, Ramón, ed., Calepino de Motul, Diccionario maya-español, México, unAM, 1995.

Dirección General de Estadística a Cargo del Dr. Antonio Peñafiel, Censo General de la República Mexicana Verificado el 20 de Octubre de 1895, Estado de Yucatán, México, Oficina Tip. de la Secretaría de Fomento, 1899.

La Revista de Mérida (LRM).

La Unión Yucateca, Periódico Oficial del Estado Libre y Soberano de Yucatán (LUY).

Memoria que presentó el Ciudadano Gobernador del Estado de Yucatán, Octavio Rosado a la Honorable Legislatura, 1884. Anexo 18, Mérida, Imprenta de Echánove y López, 1884.

${ }^{69}$ Las langostas son portadoras de parásitos, entre los que se incluyen diversas bacterias. Un estudio realizado en laboratorio, en Yucatán, permitió observar que rociando langostas vivas con un caldo de langostas putrefactas de 48 horas, moría $96 \%$ del grupo de estudio. La capacidad insecticida del caldo fue atribuida a Proteus vulgaris y a Streptococcus spp. que fueron aisladas tanto del caldo como del hemoceloma de los insectos muertos. Sin embargo, como ha señalado Harvey, hacen falta más estudios. Véase David Alonso Parra, Julián Granados C., J. Carlos Trejo Torres, "Exploración de microorganismos en Schistocerca piceifrons Walker (Orthóptera) para su control biológico. I", Xanum, 2, 9, julio, 1990, 1-5. A. W. Harvey, op. cit., p. 181.

${ }^{70}$ Santiago Domínguez Aké, op. cit., p. 218. 
Pío Pérez, Juan, Diccionario de la lengua maya, Mérida, Imprenta Literaria, 1866-1877.

\section{BiBLIOGRAFÍA}

Alonso Parra, David, Julián C. Granados, J. Carlos Trejo ToRRES, "Exploración de microorganismos en Schistocerca piceifrons Walker (Orthóptera) para su control biológico. I", Xanum, 2, 9, julio, 1990, 1-5.

Ancona, Eligio, Colección de leyes, decretos, órdenes y demás disposiciones de tendencia general: expedidas por el poder legislativo del estado de Yucatán, formada con autorización del gobierno, 31 de diciembre de 1850 hasta 30 de setiembre de 1858, vol. 6, Mérida, El Eco del Comercio, 1887.

Astor-Aguilera, Miguel Ángel, The Maya World of Communicating Objects: Quadripartite Crosses, Trees, and Stones, Albuquerque, University of New Mexico Press, 2011.

Aznar Mendoza, Enrique, "Historia de la industria henequenera desde 1919 hasta nuestros días", en Enciclopedia Yucatanense, México, vol. III, 1977, 727-787.

BARCELó QuintaL, Raquel, "La oligarquía henequenera. Un estudio de caso: La familia Escalante", Tesis de Licenciatura en Antropología Social, Escuela de Ciencias Antropológicas, Mérida, UADY, 1982.

Barrera Vásquez, Alfredo, "La significación de los morfemas Zac (Saak') y Chiic (Ciik) en los nombres Sacbe y Sacchik (Sensontle)", Estudios lingüísticos. Obras completas, volumen 2, Mérida, Fondo Editorial de Yucatán, 1981, 47-51.

Barrera VÁsquez, Alfredo, Silvia Rendón, El Libro de los Libros del Chilam, México, FCE, 1948.

Barrientos Lozano, Ludivina et al., Manual técnico sobre la langosta voladora (Shistocerca piceifrons piceifrons Walker, 1870) y otros Acridiodeos de Centro América y Sureste de México, San Salvador, FAO-OIRSA, 1992.

Cámara Zavala, Gonzalo, "Historia de la industria henequenera hasta 1919," en Enciclopedia Yucatanense, tomo III, México, Gobierno del Estado de Yucatán, 1977, 657-725. 
Domínguez Aké, Santiago, La milpa en Muxupip, México, Letras Indígenas Contemporáneas, Dirección General de Culturas Populares, 1996.

DUCH GARY, Jorge, La conformación territorial del estado de Yucatán, México, Universidad Autónoma de Chapingo, 1988.

Dumond, Don E., The Machete and the Cross. Campesino Rebellion in Yucatan, Lincoln, University of Nebraska Press, 1997.

García Quintanilla, Alejandra, “'Saak' y el retorno del fin del mundo. La plaga de langosta en las profecías del katun 13 Ahau", en Ancient Mesoamérica 16, 2005, 327-344.

, "Mérida: El Sarampión de 1882", en Siglo XIX. Cuadernos de Historia, 1, 3, junio 1992, 29-53.

, "Producción de henequén, producción de hombres" en

Mario Cerutti, ed., Cinco procesos regionales, México siglo XIX, México, Editorial Claves Latinoamericanas, 1985, 114-148.

, "Zaatal: Cuando los milperos perdieron el alma. Una historia de los mayas (Yucatán, 1880-1889)", Tesis Doctoral, University of North Carolina at Chapel Hill, 1999.

Harvey, A. W., "Schistocerca piceifrons (Walker) (Orthoptera: Acrididae), the Swarming Locust of Tropical America: a Review", Bulletin of Entomological Research 73, 1983, 171-184.

Kunn, Gerald G., "The Impact of Volcanic Eruptions on Worldwide Weather", 21st. Century. Science \& Technology, invierno 1997-1998, 48-58.

LANDA, Diego de, Relación de las cosas de Yucatán, Introducción de José Ma. Garibay, México, Ed. Porrúa, 1978.

LapoInTe, Marie, Los mayas rebeldes de Yucatán, Mérida, Maldonado Editores, Gobierno del Estado de Yucatán, 1997.

Mignolo, Walter, Desobediencia epistémica: Retórica de la modernidad, lógica de la colonialidad y gramática de la descolonialidad, Buenos Aires, Ediciones del Signo, 2010.

Pereyra Cuevas, Eudaldo, "Biología, ecología y control de la langosta Schistocerca piceifrons (Walker) (Orthoptera acrididae) en el Estado de Yucatán", Tesis, Universidad Autónoma de Chapingo, 1991.

Reed, Nelson, La Guerra de Castas de Yucatán, México, Era, 1971. 
Roberts, Walter Orr, Henry Lansford, The Climate Mandate, San Francisco, W. H. Freeman and Company, 1979.

Roys, Ralph L., The Book of Chilam Balam of Chumayel, Norman, University of Oklahoma Press, 1967.

SuÁrez Molina, Víctor, La evolución económica de Yucatán. A través del siglo XIX, México, volumen 1, Ediciones de la Universidad de Yucatán, 1977.

Terán, Silvia, Christian Rasmussen y Olivio May Cauich, Las plantas de la milpa entre los mayas, Mérida, Fundación Tun Ben Kin, A. C., 1998.

Trujillo G., Pedro, El problema de la langosta, Tijuana, Sociedad de Geografía y Estadística de Baja California, Correspondiente Tijuana, 1975.

Villers Ruiz, Lourdes, Rosa María López Franco, Alfredo BARRERA MARÍN, "La unidad habitación tradicional campesina y el manejo de recursos bióticos en el área maya yucatanense", Biótica 6, 3, 1981, 293-323.

FeCha de RECEPCión Del ARTí́culo: 5 de julio de 2011

FECHA DE ACEPTACIÓN Y RECEPCIÓN DE LA VERSIÓN FINAL: 17 de octubre de 2011 